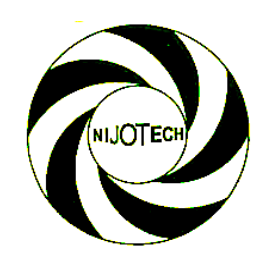

Nigerian Journal of Technology (NIJOTECH)

Vol. 37, No. 3, July 2018, pp. 619 - 625

Copyright@ Faculty of Engineering, University of Nigeria, Nsukka,

Print ISSN: 0331-8443, Electronic ISSN: 2467-8821 www.nijotech.com

http://dx.doi.org/10.4314/njt.v37i3.9

\title{
ASSESSMENT OF RUNWAY EXCURSION CAUSAL FACTORS AND MITIGATION STRATEGIES
}

\author{
E. G. Okafor ${ }^{1,{ }^{*}, \text { P. O. Jemitola }}{ }^{2}$ and M. A. Soladoye ${ }^{3}$

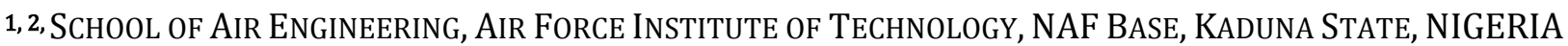 \\ 3, LinKage Services, Kwara State University, PMB 1530 Malete, KWARA State, NigERIA \\ E-mail addresses:1eg.okafor@gmail.com, ${ }^{2}$ pojemitola@yahoo.co.uk, ${ }^{3}$ musibau.soladoye@kwasu.edu.ng
}

\begin{abstract}
Runway excursion (RE) is a significant cause of many aircraft accidents worldwide. Statistic reveals that accident associated with $R E$ is on the increase. Although $R E$ accident fatalities are usually lower with respect to loss of control (LOC) caused accidents, however the aircrafts involved in RE caused accidents are usually write-off. In response to the raising threat to aviation safety, the Research and Development (R\&D) division of the Air Force Institute of Technology (AFIT), Nigerian Air Force (NAF) Base, Kaduna Nigeria was tasked to conduct a study on RE problem. The study gathered of three kinds of secondary information associated with RE accidents: 1) statistical summaries, 2) accident report that cited runway excursion accident and 3) stakeholders inputs. Using this resources, the RE causal factors were identified. This paper described the study method, stakeholder viewpoint; key identified causal factors for RE caused accidents and mitigation strategies.
\end{abstract}

Keywords: Aircraft accident, causal factor, runway excursion, mitigation strategies

\author{
Nomenclature \\ AFIT Air Force Institute of Technology \\ ARC Abnormal runway contact \\ CFIT Controlled flight into or toward terrain \\ DBR Damaged beyond repair \\ F-NI Fire/Smoke (non-impact) \\ ICAO International civil aviation organization \\ MAC Midair / near midair collision \\ MGW Maximum ground weight. \\ NOTAM Notice to Airmen \\ OTHR Other \\ RAMP Ground handling \\ RE Runway excursion (takeoff and landing) \\ Ri-VAP Runway incursion \\ R\&D Research and Development \\ SCF- PP System/Component failure or malfunction \\ (power-plant) \\ UNK Unknown undetermined \\ USOS Understoot/Overshoot \\ WSTRW Windshear or thunderstorm
}

\section{INTRODUCTION}

Over years, numerous aircraft accidents have occurred with varied degree of fatalities. Post investigation reports usually associate each incident with a single or a combination of causal factors. Some of the common causal factors are loss of control; control flight into or toward terrain; force landing outside airport; fuel starvation; midair/near midair collision; ground handling, runway excursion; runway incursion; system/component failure or malfunction (Powerplant and Non-Powerplant); undershoot/overshoot; windshear or thunderstorm and arson attack. Of all these possible aircraft accident causal factors, "loss of control" accidents has attracted attention as a result of their status as the most common type of accident, especially with respect to the number of fatalities they produce [1]. However, critical evaluation of other causal factors revealed that "runway excursion" contributes significantly to the total number of aircraft accidents or incidents cases [2]. According to the International Civil Aviation Organization (ICAO), Runway excursion is simply a veer off or overrun off the runway surface or an incident involving only a single aircraft, where it make an inappropriate exit from the runway.

A key motivator for aviation safety research is the annual Boeing Statistics of Commercial Jet Airplane Accidents. A chart from the 2015 report is shown in Figure 1. 
Worthy of note are issues not considered in Figure 1. They are:

1. It does not include statistics of aircraft manufactured in the commonwealth of independent states or Union of Soviet Socialist Republic (USSR)

2. It does not include statistics of aircrafts used for military operations.

3. It only included statistics of aircrafts weighing more than 60000lb maximum gross weight (MGW).

While Figure 1 shows loss of control as the most significant classification of aircraft accident, a closer look at the figure reveals that runway excursion is equally a significant contributor (approximately 21\%) to all fatal aircraft accidents cases.

An assessment of the Boeing statistical report from 1999-2008 and 2005-2014 as shown in Table 1, reveals a quick raise in the percentage contribution of runway excursion to the total fatalities (onboard and external) form $13 \%$ - 20\% for landing, ARC, USOS and takeoff condition as compared to loss of control which rose from $40 \%-41.7 \%[4,5]$. Notwithstanding an overall decline in the total fatalities for the periods considered. The team in attempt to gain insight into the root causes of runway excursion related accidents examined all aircraft accidents within West African region with the goals of understanding the nature of these accidents and indentifying the underlying causal and contributing factors. A summary of the West African aircraft accidents are as shown in appendix I.

According to Piyush and Hemantkumar [6] runway excursion can be categorized as either veer off or overrun. Runway veer off occurs when aircraft veer off the side of the runway during landing roll or exiting the runway. Overrun on the other hand occur when the aircraft rollout extends beyond the end of the runway [6]. Contamination of runway greatly increases the probability of runway excursion occurance. Examples of common contaminants includes surface water more than $3 \mathrm{~mm}$ deep, rubber deposits, snow, frost and other deposit such as sand, mud, oil, etc. The effect of runway contamination includes reduced friction between aircraft tyres and the runway surface as well as aquaplaning [6].

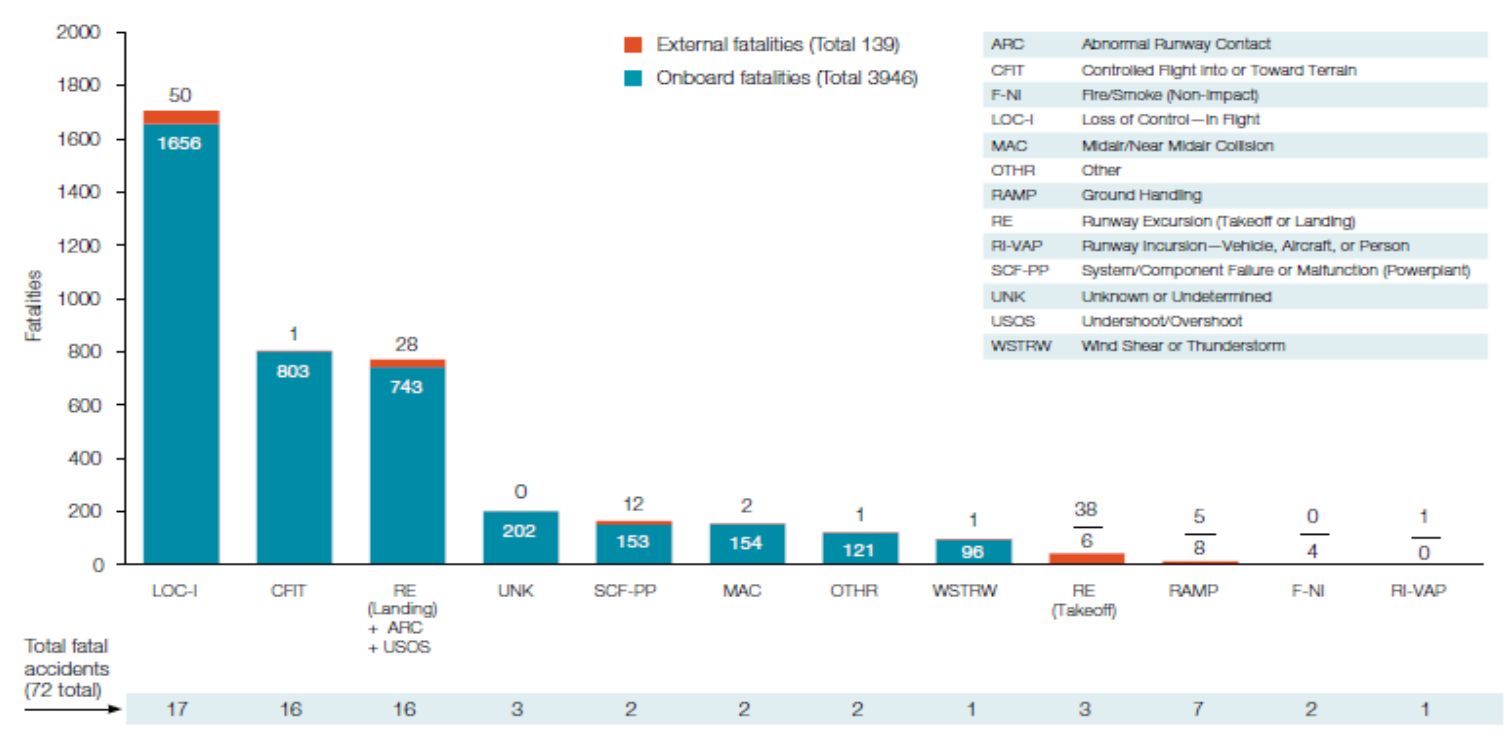

Figure 1 Worldwide fatal accident by occurrence category 2005-2014 [3]

Table 1: Comparison of LOC and runway excursion fatalities from 1999-2008 and from 2005-2014 [4, 5]

\begin{tabular}{|c|c|c|c|c|c|c|}
\hline \multirow[t]{2}{*}{ Study Duration } & \multicolumn{2}{|c|}{ LOC Fatalities } & \multicolumn{2}{|c|}{$\begin{array}{c}\text { Runway Excursion } \\
\text { Fatalities }\end{array}$} & \multicolumn{2}{|c|}{ Total Fatalities } \\
\hline & Onboard & External & Onboard & External & Onboard & External \\
\hline 1999-2008 & 1926 & 65 & 554 & 92 & 4717 & 253 \\
\hline $2005-2014$ & 1656 & 50 & 749 & 64 & 3946 & 139 \\
\hline $\begin{array}{l}\text { Percentage Change (1999-2008)-(2005- } \\
2014)\end{array}$ & \multicolumn{2}{|c|}{$40-41.7 \%$} & \multicolumn{2}{|c|}{$13-20 \%$} & \multicolumn{2}{|c|}{$-17.5 \%$} \\
\hline
\end{tabular}


In response to the increasing threat to aviation safety and the improvement of understanding on runway excursion problem as it affects aviation safety, the Research and Development (R\&D) division of the Air Force Institute of Technology (AFIT), Nigerian Air Force base Kaduna, Nigeria was mandated to carry out a study of the causal factors of runway excursion and mitigation strategies. Thus, this paper reviews the main causal factors of the runway excursion hazard, and mitigation strategies as identified by the R\&D division of AFIT.

\section{MATERIALS AND METHODS}

\subsection{Runway Excursion Study Team}

The AFIT R\&D division team consisted of five engineers involving three (3) and two (2) AFIT and the Nigeria Air Force (NAF) staff members respectively. All the team members have excellent background in Aviation Safety Program with skills that include aircraft and airport design and maintenance, flight research, flight dynamics, flight training, human performance and error.

\subsection{Study Method and Rationale}

In order to successfully carry out this study, the R\&D division of AFIT adopted the steps itemized below:

1. Reviewed statistical summary report for RE accidents

2. Analysed the West African aircraft accident data archives of the Aviation Safety Network database

3. Discussed with stakeholders and analysis $\mathrm{RE}$ accidents reports

4. Prioritized causal factor and identified candidate mitigation

5. Research findings and conclusion

A number of recent studies were reviewed and analyzed as part of R\&D division of AFIT efforts towards identifying the runway excursion causal factors [7-8]. Two of those studies have been presented in a manner of relevance to this study: the 2015 Boeing Statistical Summary of Commercial Jet Airplane Accidents and an analysis of West African accident data by R\&D of AFIT division.

\subsection{Data Collection}

Historical data obtained from Aviation Safety Network database as well as personnel interview of key aviation industry stakeholders were the main sources of data for these study. Five (5) selected highly competent persons with both technical and practical experiences on aircraft accident/incident investigation were interviewed, by two well trained interviewers. Each interviewer used structured questions designed for a 20 minutes interview.

\subsection{Sampling}

In attempt to incorporate stakeholders input, judgmental sampling was implemented in this work. All interviewed stakeholders selected from FAAN have over 20 years of both technical and practical experience on aircraft accident investigation.

\subsection{Data Analysis}

Tables were used to present the results of the study and in depth discussions of the study findings were made, based on the historical data and stakeholders input.

\section{RESULTS AND DISCUSSION}

\subsection{Historical Data}

Although, the accidents cited in the Boeing annual report are good indicators for worldwide recent accident statistics involving larger aircraft, more data are needed to gain insight into the causal factors for both incidents and accidents for all aircraft weight. The R\&D division of AFIT conducted a study of aircraft accidents that occurred in the entire West African region from 1995 - 2015 to identify runway excursion events and causal factors using accident reports as documented in the Aviation Safety Network database, as well as stakeholders input in order to identify causal factors related to runway excursion for all range of operations. Table 2 shows the number of accident as well as the number of runway excursion events which has occurred in the West African Region from 19952015.

From Table 2, a total of 26 runway excursion classified accidents have occurred in the West African region. The team therefore, reviewed accident summaries for each of the 26 runway excursion classified accidents with the aims of understanding the nature of these accidents and identifying the underlying causal factors. Table 3 through 5 shows data describing West African runway excursion accidents.

Table 2: West African Countries in which aircraft accidents and runway excursion accidents occurred, 1995-2015 [7]

\begin{tabular}{lcc}
\hline Country & $\begin{array}{c}\text { Number of } \\
\text { Accidents }\end{array}$ & $\begin{array}{c}\text { Number of Runway } \\
\text { Excursion Accidents }\end{array}$ \\
\hline Benin & 2 & 1 \\
Burkina Faso & 1 & 0 \\
Cape Verde & 2 & 1 \\
\hline
\end{tabular}




\begin{tabular}{lcc}
\hline Country & $\begin{array}{c}\text { Number of } \\
\text { Accidents }\end{array}$ & $\begin{array}{c}\text { Number of Runway } \\
\text { Excursion Accidents }\end{array}$ \\
\hline Gambia & 1 & 0 \\
Ghana & 6 & 4 \\
Guinea & 3 & 2 \\
Guinea Bissau & 0 & 0 \\
Ivory Coast & 5 & 1 \\
Liberia & 6 & 3 \\
Mali & 6 & 0 \\
Mauritania & 5 & 0 \\
Niger & 5 & 1 \\
Nigeria & 49 & 11 \\
Sao-Tome and & 3 & 0 \\
Principe & 5 & 1 \\
Senegal & 4 & 1 \\
Sierra Leone & 0 & 0 \\
St. Helena & 1 & 0 \\
Togo & 104 & 26 \\
\hline Total & & \\
\hline
\end{tabular}

Table 3: Runway excursion accidents that occurred in each causal factor category, 1995-2015

\begin{tabular}{lll}
\hline & $\begin{array}{l}\text { Number of } \\
\text { runway } \\
\text { excursion } \\
\text { accidents }\end{array}$ & $\begin{array}{l}\text { Number of } \\
\text { runway } \\
\text { excursion } \\
\text { accidents as } \\
\text { contributing } \\
\text { factor }\end{array}$ \\
\hline $\begin{array}{l}\text { Environmentally } \\
\text { induced }\end{array}$ & 11 & 9 \\
System induced & 8 & 4 \\
Human induced & 7 & 3 \\
\hline
\end{tabular}

Some important generalized findings as derived from the data presented in Table 3 through 5 are listed below.

1. Out of the 26 accidents in the runway excursion category, the leading causal factors fall within environmentally induced category.

2. Nigeria is the major (42.3\%) contributor to the overall runway excursion accident within the West African region.

3. The majority (approximately 81\%) of the recent runway excursion occurred during the landing phase in which the aircraft is relatively close to or on the ground, leaving little time for corrective action.

4. Flight crew inadequate training, improper procedure, poor crew and energy management are a significant factor in runway excursion accidents.

While analysis of West African accident report provided insights into the RE causal factor, inclusion of expert viewpoint was essential. The preceding section provides a summary of stakeholder's viewpoint on the focus of this study.

\subsection{Stakeholders Viewpoint}

Oral interview with selected Federal Airport Authority of Nigerian (FAAN) staff members and study of reports of aircraft RE accidents revealed that RE can be accelerated by prevailing hazards, which usually vary from one country or location to the order. A brief summary of these airport based hazards is shown in Table 6 below.

From Table 6 which was in agreement with the work of ref. [8] as well as the categories already presented as shown in Table 3, it was imperative that the stakeholders favoured environmental and human induced factors as the key cause of runway excursion. For instance, heavy rain may have high tendency to cause aqua planning that could result to runway excursion. However, runway not accurately designed for effective friction and drainage may trigger the hazard, and therefore result into RE event. Also the construction equipment and position may impact the severity of an excursion event. Furthermore, failure to notify a pilot on an emergency closure of a runway or placement of Notice to Airmen (NOTAM) which may not have been read by a pilot can cause or contribute to RE event severity.

Table 4: Causal factors contributing to runway excursion aircraft accidents in West Africa, 1995-2015 Causal Factors Number of Fatal Accidents with Causal Factor

\begin{tabular}{ll}
\hline \multicolumn{2}{c}{ Environmentally induced } \\
\hline Rain /thunderstorm & 7 \\
Low base cloud & 3 \\
Wind shear & 2 \\
Sand storm & 1 \\
\hline \multicolumn{2}{c}{ System induced } \\
\hline Aircraft system failure & 7 \\
Poor design & 3 \\
\hline \multicolumn{2}{c}{ Human-induced } \\
Poor energy/crew & \\
management & 5 \\
Inadequate training & 4 \\
\hline Improper procedure & 2 \\
Poor maintenance & 1 \\
Spatial disorientation & 1 \\
Crew incompatibility & 1 \\
Poor design & 1 \\
\hline
\end{tabular}

Table 5: Phase of flight in which runway excursion accidents that occurred, 1995-2015

\begin{tabular}{lc}
\hline \multicolumn{1}{c}{ Phase of Flight } & Number of accidents \\
\hline Takeoff & 5 \\
Landing & 21 \\
\hline
\end{tabular}


Table 6: Airport stakeholder's viewpoint on runway potential causal factors

\begin{tabular}{|c|c|}
\hline Potential Hazards & Hazards components \\
\hline Visibility & $\begin{array}{l}\text { - Inhospitable terrain (eg runway in valley surrounded by hills and buildings } \\
\text { - } \\
\text { - } \quad \text { Imposition of sun to the human eye. } \\
\text { - Runway not designed and maintained to maximize drainage and effective } \\
\text { friction. }\end{array}$ \\
\hline Construction & $\begin{array}{ll}\text { - } & \text { Aircraft miscalculate load or performance } \\
\text { - } & \text { Location of construction equipment }\end{array}$ \\
\hline Airport & $\begin{array}{ll}\text { - } & \text { Poor airport pavement management system } \\
\text { - } & \text { Poor airfield ground lighting } \\
\text { - } & \text { Unclear marking on runways }\end{array}$ \\
\hline Communication & $\begin{array}{ll}\text { - } & \text { Non effective relay of runway condition } \\
\text { - } & \text { Failure to notify pilot of runway closure }\end{array}$ \\
\hline
\end{tabular}

\section{MITIGATION STRATEGIES}

Runway excursion accidents are majorly caused by factor external to the aircraft. Generally, few accidents have a single cause. These causes may have to line up to form a chain capable of causing a runway excursion accident. Any successful attempt to break the link in the runway accident sequence or chain could lead to an avoidance of what could have been a runway excursion event. A single environmentally induced trigger can create varied scenarios, however the resultant runway excursion accident can be prevented by several potential mitigation strategies. Rain was found to be the top candidate causal factor, in the environmentally induced runway excursion incident. An efficient approach to address the rain issues includes designing the runway with grooves so as to increase friction, reduce aqua planning and efficient water dispensation. The selection of runway porosity must be giving due consideration especially with regards to water seepage. The adherence to standard operating procedure in adverse weather condition as well as the use of improved technology essential for effective decisionmaking regarding RE avoidance and intensification of research on environmental avoidance technology will be of great benefit.

The West African accident statistics indicates that human-induced runway excursion is also a key contributor. The AFIT team categorized the prominent human-induced runway excursion causal factor as poor crew and energy management, spatial disorientation, improper procedures, inadequate training. Energy management implies the ability to know and control the complex combination of the aircraft altitude and vertical speed, thrust and configuration, and air speed trend. Poor energy management leads to distraction and de-stabilized approaches. In the case were the aircraft is close to the ground, the situation is usually lethal. The situation may be worse coping with windshear during final approach. Wind shear can decrease or increase airspeed until engine thrust has no opportunity to reestablish the proper airspeed within the new air mass. One effective way to deal with this is:

1. Convert tower winds to a headwind or tail wind component

2. Determine aircraft approach speed for configuration crossing the runway threshold

3. Compute minimum ground speed by subtracting the headwind from the approach speed or adding the tailwind

4. Once the airplane is in approach configuration, monitor actual ground speed

While the steps itemized above are a valid approach to deal with wind shear of one air mass sitting atop another. It should not be employed when dealing with convective activity, especially a microburst, where magnitude of the speed loss or gain can be unpredictable.

Furthermore, human induced error may occur as a result of inexperience staff in reporting runway condition as well as aircraft miscalculated load and performance as shown in Table 6. Thus, there is need for effective training on the accurate assessment and reporting procedures for runway condition. Other studies have laid emphasis on the effect of automation and pilot misunderstanding of automation. Poor feedback of automation system as well as the increased complexity have been itemized as the key contributor to human induced runway excursion with respect to automation. Beneficial effort such as the use of standardize paint and establishment of optimal runway painting frequency, periodic assessment of airfield ground lighting management, as well as standardize predictive and preventive maintenance program, 
runway data collection, rehabilitation and reconstruction program are essential for reduced the severity RE event. Key consideration should be give to appropriate obstacle (hills, trees and building etc.) and provision should be made during runway construction aircraft to accommodate steer back into runway especially in cases of veer off during thunderstorm.

System induced runway excursion is second to environmentally induced runway excursion causal factors. Although modern aircrafts systems are extremely safe and flight critical components have a failure probability of $10^{-9}$ per hour of operation [1]. Notwithstanding stringent reliability guidelines, systems failures of safety critical system such as the landing gear have been repetitively associated with many runway excursion incidents. Improved research effort is therefore needed in the design of robust landing capable of landing on surfaces of varied condition and characteristics.

Generally, the mitigation strategies provided are not all encompassing, they only represents the current trend and future direction towards reduction of runway excursion occurrences and severity reduction.

\section{CONCLUSION}

In this study, statistical summary as well as accident report and stakeholder's viewpoint were used in order to identify the causal factor associated with RE accidents. Although the causal factors have been organized into three categories; environmentallyinduced, human-induced and system induced, no single category is solely responsible for RE accidents, rather accident occur when combination of failure happen across human and engineering system in the presence of an external environment.

Environment causal factor are most significant contribution to runway excursion accidents when compared to system and human induced casual factors. Generally, environmentally induced accident mitigation should focus on efficient monitoring of the weather condition in order to make decision such as delay or cancellation of flight as well as coordinating research geared towards technologies to avoid weather and atmospheric related RE events. Further more environmentally induced component such as heavy rain should be reduced through design to ensure optimal seepage and effective friction.
RE accidents have also been found to be human induced especially with regards to lack of communication of runway condition, aircraft miscalculated load and performance. Mitigation strategy should thus focus on training especially for emergency response and monitoring of adherence to operating procedures, standardization of prediction and preventive maintenance program, periodic data mining, optimal reconstruction and rehabilitation program. While modern aircraft system design is highly reliable, attention should be focused on improving landing gear design considering undershoot and overshoot cases on varied surface conditions as well as optimal maintenance so as to reduce the collapse of landing gears associated with many RE accidents.

\section{ACKNOWLEDGEMENT}

This study has been greatly supported by the Air Force Institute of Technology, NAF base Kaduna and the Nigeria Air Force.

\section{REFERENCES}

[1] Steven, R. J. "Aircraft Loss of Control Causal Factors and Mitigation Challenges" AIAA 2010

[2] Eunsun, R. and Seth, Y. “General Aviation Runway Design Evaluation based on Aircraft Deviation from Runway Centerline" Doctoral Symposium ICRAT 2016

[3] International Air Transportation Association, Safety Report 2014, April 2015

[4] The Boeing Company, "Statistical Summary of Commercial Jet Airplane Accidents" Worldwide Operations 1959-2008, Jul 2009.

[5] The Boeing Company, "Statistical Summary of Commercial Jet Airplane Accidents" Worldwide Operations 2005-2014, Aug 2015.

[6] Piyush, G. and Hemantkumar, G. S. "Runway Excursion: A Problem" IOSR Journal of Mechanical and Civil Engineering Vol. 11 Issue 3, 2014, pp. 75-78

[7] Aviation Safety Network, URL: https://aviationsafety.net

[8] Dato, A. M. "The Airport operator's perspective on Runway Excursion Hazards", ICAO The Asia Pacific Regional Runway Safety Seminar (APAC) 21-24 May, Bali Indonesia 2012 


\section{APPENDIX I: A SUMMARY OF THE WEST AFRICAN AIRCRAFT ACCIDENTS (1995-2015)}

\begin{tabular}{|c|c|c|c|c|c|c|}
\hline Country & Date & $\begin{array}{l}\text { Flight } \\
\text { phase }\end{array}$ & $\begin{array}{l}\text { Aircraft } \\
\text { damage }\end{array}$ & Fatalities & $\begin{array}{l}\text { Aircraft } \\
\text { fate }\end{array}$ & Details \\
\hline Benin & $04 / 02 / 2004$ & Takeoff & Substantial & 0 & Repaired & $\begin{array}{l}\text { Tyre burst on take. Overrun } \\
\text { while landing at Cotonou }\end{array}$ \\
\hline $\begin{array}{l}\text { Cape } \\
\text { Verde }\end{array}$ & $28 / 09 / 1998$ & Landing & $\begin{array}{l}\text { Damage } \\
\text { beyond } \\
\text { repair (DBR) }\end{array}$ & 1 & DBR & Change in wind direction \\
\hline \multirow{4}{*}{ Ghana } & $19 / 03 / 2003$ & Takeoff & Substantial & 0 & & \multirow{4}{*}{$\begin{array}{l}\text { EFIS tubes went blank } \\
\text { Landing gear collapsed on } \\
\text { takeoff } \\
\text { Thunderstorm resulted to } \\
\text { the inability of the aircraft to } \\
\text { stop on runway } \\
\text { Flat tyre upon landing and } \\
\text { poor visibility. }\end{array}$} \\
\hline & $21 / 08 / 2003$ & Takeoff & Substantial & 0 & & \\
\hline & $2 / 06 / 2012$ & Landing & DBR & $\begin{array}{l}0 \\
(\mathrm{GC}=12)\end{array}$ & DBR & \\
\hline & $10 / 01 / 2015$ & Landing & Substantial & & DBR & \\
\hline \multirow[b]{2}{*}{ Guinea } & $26 / 01 / 1995$ & Takeoff & DBR & 0 & DBR & \multirow{2}{*}{$\begin{array}{l}\text { Overrun runway } \\
\text { Heavy rain led to runway } \\
\text { overrun. }\end{array}$} \\
\hline & $28 / 07 / 2010$ & Landing & Substantial & 0 & DBR & \\
\hline $\begin{array}{l}\text { Ivory } \\
\text { Coast }\end{array}$ & $12 / 04 / 1997$ & Landing & Substantial & 0 & DBR & $\begin{array}{l}\text { Heavy rain and poor visibility } \\
\text { and collapsed landing gear }\end{array}$ \\
\hline \multirow{3}{*}{ Liberia } & $25 / 06 / 1995$ & Landing & DBR & 0 & DBR & $\begin{array}{l}\text { Pilot flown at low and } \\
\text { dangerous approach and } \\
\text { substandard runway as well } \\
\text { as rain. }\end{array}$ \\
\hline & $25 / 07 / 1996$ & Landing & DBR & 0 & \multirow[t]{2}{*}{ DBR } & $\begin{array}{l}\text { Wind shear led to runway } \\
\text { undershoot alongside } \\
\text { collapsed gear }\end{array}$ \\
\hline & $23 / 03 / 2001$ & Landing & DBR & 0 & & $\begin{array}{l}\text { Lost of visual contact with } \\
\text { ground }\end{array}$ \\
\hline Niger & $27 / 04 / 2010$ & Landing & Substantial & 0 & DBR & $\begin{array}{l}\text { Sand Storm impaired } \\
\text { visibility and landing gear } \\
\text { collapse. }\end{array}$ \\
\hline \multirow{10}{*}{ Nigeria } & $24 / 06 / 1995$ & Landing & & 16 & \multirow[t]{10}{*}{ DBR } & \multirow{10}{*}{$\begin{array}{l}\text { Heavy rain, low cloud base } \\
\text { Human error (Crew } \\
\text { incompatibility/Inadequate } \\
\text { training/ poor equipment) } \\
\text { Inadequate weather } \\
\text { information/VOR Navigation } \\
\text { an incorrect radial of the } \\
\text { runway. } \\
\text { Human error } \\
\text { Bad weather } \\
\text { Heavy rain } \\
\text { Poor crew management/bad } \\
\text { weather } \\
\text { Human error }\end{array}$} \\
\hline & $13 / 11 / 1995$ & Landing & & 11 & & \\
\hline & $29 / 11 / 2003$ & Landing & & 0 & & \\
\hline & $06 / 09 / 2004$ & Takeoff & & 0 & & \\
\hline & $12 / 06 / 2005$ & Landing & & 0 & & \\
\hline & $07 / 09 / 2006$ & Landing & & 0 & & \\
\hline & $12 / 03 / 2010$ & Landing & & 0 & & \\
\hline & $10 / 07 / 2011$ & Landing & & 0 & & \\
\hline & $14 / 07 / 2011$ & Landing & & 0 & & \\
\hline & $4 / 12 / 2013$ & Landing & & 0 & & \\
\hline Senegal & $06 / 02 / 2005$ & Landing & Substantial & 0 & Repaired & Poor visibility (night landing) \\
\hline $\begin{array}{l}\text { Sierra } \\
\text { Leone }\end{array}$ & $31 / 12 / 2007$ & Landing & Substantial & 0 & Repaired & $\begin{array}{l}\text { Mechanical failure (landing } \\
\text { gear separation) }\end{array}$ \\
\hline
\end{tabular}

